\title{
Konsep Pemberdayaan Nelayan Pesisir Kota Surabaya Sebagai Bentuk Adaptasi Perubahan Iklim Berbasis Sustainable Livelihood
}

\author{
Ardiyanto Maksimilianus Gai \\ Program Studi Perencanaan Wilayah dan Kota, Institut Teknologi Nasional Malang \\ ardiyanto maksimilianus@lecturer.itn.ac.id
}

INFO ARTIKEL
Riwayat Artikel:
Diterima: 27-02-2020
Disetujui: 29-04-2020

Kata Kunci:

Pemberdayaan

Nelayan

Perubahan Iklim

Sustainable Livelihood

Kota Surabaya

\begin{abstract}
ABSTRAK
Abstrak: Permasalahan sosial, ekonomi dan ekologi pada kawasan pesisir merupakan permasalahan penting yang terikat satu sama lain. Profil perikanan pada Dinas Pertanian Kota Surabaya menunjukkan bahwa tingkat kesejahteraan nelayan dan akses sumber daya manusia di kawasan pesisir rendah. Selain itu, kondisi pesisir semakin menurun akibat adanya perubahan iklim. Konsep pendekatan mengenai penghidupan yang berkelanjutan (sustainable livelihood) merupakan salah satu bentuk metode yang dapat mengatasi permasalahan di wilayah pesisir. Penelitian ini menggunakan pendekatan deskriptif kualitatif, dengan subjek penelitian masyarakat nelayan pesisir di Kota Surabaya. Variabel yang digunakan adalah modal sosial, modal alam, modal fisik, modal manusia dan modal finansial. Hasil penelitian menunjukkan bahwa faktor modal manusia memiliki peranan paling penting dalam rangka meningkatkan kesejahteraan masyarakat nelayan. Sehingga diperlukan konsep dan langkah pemberdayaan sesuai dengan masing-masing variabel terkait penghidupan berkelanjutan (sustainable livelihood).
\end{abstract}

\begin{abstract}
Social, economic, and ecological problems in coastal areas are important issues that are bound to one another. The Fisheries profile at Dinas Pertanian Kota Surabaya shows that the level of fishermen's welfare and access to human resources in the coastal area are low. Besides, coastal conditions are declining due to climate change. The concept of an approach to sustainable livelihood is one method that can overcome problems in coastal areas. This study uses a qualitative descriptive approach with coastal fishing communities in Surabaya City as research subjects. The variables used are social capital, natural capital, physical capital, human capital, and financial capital. The results show that the human capital factor has the most important role to improve the welfare of the fishing community. Therefore, the empowerment concepts and steps are needed in accordance with each variable related to a sustainable livelihood.
\end{abstract}

\section{A. LATAR BELAKANG}

Permasalahan sosial, ekonomi dan ekologi pada kawasan pesisir merupakan permasalahan penting yang terikat satu sama lain [1]. Salah satunya adalah keterkaitan faktor kemiskinan dan faktor pengelolaan lingkungan. Kondisi ini terjadi pada kawasan pesisir di Kota Surabaya. Profil perikanan pada Dinas Pertanian Kota Surabaya pada tahun 2012 menunjukkan bahwa tingkat kesejahteraan nelayan dan akses sumber daya manusia di kawasan pesisir rendah. Hal ini terlihat dari rendahnya pendapatan nelayan di pesisir timur Kota Surabaya, sebanyak 29,30\% masih dibawah UMK Kota Surabaya.

Selain itu, kondisi lingkungan semakin menurun akibat adanya perubahan iklim. Masyarakat pesisir, nelayan tangkap dan pembudidaya di tanah air telah mengalami dampak perubahan iklim di sektor perikanan salah satunya berkutangnya produktivitas perikanan karena rusaknya ekosistem mangrove dan terumbu katang akibat kenaikan suhu permukaan air laut dan perubahan rezim air tanah [2].

Rendahnya kesejahteraan dan sumber daya manusia di kawasan pesisir Kota Surabaya serta adanya ancaman perubahan iklim menjadi penyebab langsung pada penurunan hasil produksi perikanan. Hal ini akan menyebabkan semakin menurunnya tingkat kesejahteraan masyarakat nelayan.

Perlu adanya konsep yang tepat untuk menanggulangi permasalahan yang ada pada kawasan pesisir. Konsep pendekatan mengenai penghidupan yang berkelanjutan (sustainable livelihood/SLA) merupakan salah satu bentuk metode untuk meningkatkan pemahaman penghidupan rumah tangga miskin [2]. Pendekatan ini dipilih dikarenakan derajat pemenuhan kebutuhan sosial, ekonomi dan ekologi dilakukan secara adil dan seimbang dengan mengkombinasikan aktivitas dan utilisasi modal-modal yang ada dalam tata sistem kehidupan [3]. Diharapkan dengan konsep pendekatan ini akan membantu 
masyarakat nelayan pesisir Kota Surabaya menjadi lebih mendiri dan berdaya dalam upaya adaptasi terhadap perubahan iklim.

Penelitian ini bertujuan untuk mendapatkan langkah yang tepat dalam meningkatkan pemberdayaan masyarakat nelayan pesisir di Kota Surabaya.

\section{B. METODE PENELITIAN}

Penelitian ini menggunakan pendekatan deskriptif kualitatif. Pendekatan ini dipilih untuk memahami fenomena sosial yang dialami subjek penelitian, yaitu masyarakat nelayan pesisir di Kota Surabaya.

Jenis sampling yang digunakan adalah nonprobability sampling atau non-random sampling, dengan pemilihan responden untuk diwawancara menggunakan snowball sampling.

Peningkatan kualitas penelitian dilakukan menggunakan teknik triangulasi. Dimana pertanyaan dengan variabel yang sama ditanyakan pada orang yang berbeda untuk dibandingkan, dianalisis kemudian membentuk kesimpulan.

Variabel pokok yang ditanyakan kepada responden terkait penelitian antara lain :

a. Modal sosial : organisasi nelayan, kepercayaan antar nelayan dan jaringan ikatan masyarakat

b. Modal alam/lingkungan : kesehatan lingkungan, produksi air, kepemilikan tanah dan produksi perikanan

c. Modal fisik : jumlah dan jenis alat, aksesibilitas, kondisi rumah, ketersediaan air bersih, kepemilikan kendaraan, kondisi sanitasi dan kondisi drainase

d. Modal manusia :tingkat pendidikan, ketrampilan dan kemampuan kerja

e. Modal finansial : pendapatan sehari, pengeluaran, jumlah dan jenis tabungan yang dimiliki dan pinjaman

\section{HASIL DAN PEMBAHASAN}

\section{Karakteristik Sustainable Livelihood di Kawasan Pesisir Kota Surabaya}

Karakteristik sustainable livelihood dilihat berdasarkan modal manusia, modal sosial, modal alam, modal finansial dan modal fisik. Nilai yang dilihat adalah kondisi, keberadaan dan kemampuan masyarakat pesisir dalam mengakses modal sesuai sustainable livelihood approach.

a. Modal sosial

Pada kawasan nelayan pesisir di Kota Surabaya, terbentuk keterikatan melalui proses rantai ekonomi. Keterikatan ini terjalin antara penangkap ikan hingga ke pedagang. Tingkat kepercayaan antar nelayan cukup erat, hal ini terlihat dari kemudahan antar nelayan untuk saling bekerja sama dan tolong menolong.

Kelembagaan yang ada di kawasan nelayan pesisir masih kurang berfungsi dengan baik. Kelompok nelayan sebagai komunitas sosial masih kurang berperan dalam optimalisasi pemberdayaan ekonomi nelayan. Selain itu, unit simpan pinjam yang dikelola oleh koperasi lokal belum dapat menjangkau seluruh masyarakat nelayan.

Kesadaran sosial masyarakat dalam upaya meningkatkan kesejahteraan dengan terlibat dalam kelembagaan atau organisasi nelayan masih rendah.

\section{b. Modal alam}

Hasil perikanan yang mendominasi adalah udang, teripang, terung, ikan tongkol, ikan tuna dan lorjuk. Jumlah yang didapat ini belum dapat mencukupi kebutuhan masyarakat nelayan pesisir. Namun, potensi lautdi kawasan pesisir Kota Surabaya masih tinggi, namun daya eksplorasi nelayan masih rendah.

Kesehatan lingkungan di permukiman kawasan nelayan pesisir Kota Surabaya buruk. Kesehatan lingkungan ini dipengaruhi dari kumuhnya kawasan dan kesadaran masyarakat akan kebersihan lingkungan masih minim. Selain itu, kondisi air bersih dikawasan nelayan pesisir juga buruk dan belum layak minum.

c. Modal fisik

Nelayan pesisir Kota Surabaya saat ini rata-rata masih menggunakan alat tangkap tradisional berupa waring atau jaring hitam dan kapal kayu < 5 GT.Sehingga dengan kapasitas kapal yang kecil, nelayan hanya mampu menangkap ikan secara tradisional dengan jarak 1 mil. Nelayan membeli bahan bakar yang digunakan untuk perahu secara ecer dan tidak menggunakan SPDN terdekat.

Aksesibilitas nelayan dari dan menuju pusat kota sudah terpenuhi. Kondisi permukiman nelayan $\pm 34,80 \%$ masih berupa semi permanen. Selain itu, lebih dari $40 \%$ rumah tangga memiliki aset tidak lengkap karena diperlukan adanya biaya selama penggunaan dan perawatan. Misalnya saja biaya untuk perawatan perahu, bahan bakar, biaya listrik untuk tv dan radio atau pembelian pulsa untuk sarana komunikasi.

Kondisi sanitasi dan drainase lingkungan rata-rata sudah diperbaiki, namun masih bergantung pada kesadaran masyarakat nelayan untuk pemeliharaannya.

\section{d. Modal manusia}

Rata-rata nelayan pesisir di Kota Surabaya masih belum mau menangkap di laut lepas. Rata-rata hanya berjarak 1 mil dengan lama waktu 2-3 jam. Hal ini juga masih disesuaikan dengan adanya pasang surut air laut. Selain itu, nelayan di Kota Surabaya juga masih ada jeda melaut \pm 2 hari, sehingga kebutuhan sehari-hari masih belum mencukupi.

Ketika masuk musim paceklik, maka nelayan akan berusaha memenuhi kebutuhan sehari-hari dengan mengandalkan mata pencaharian lainnya, misalnya buruh pabrik, berdagang, ojek, pengrajin kerang atau pekerjaan lainnya.

Tingkat pendidikan di kawasan pesisir Kota Surabaya $\pm 45 \%$ tidak bersekolah dan mayoritas tamatan SD [5]. Hal ini berdampak pada tingkat keterampilan dan kemampuan kerja masyarakat nelayan pesisir. 
Pemberian adanya bantuan berupa kapal tangkap oleh Pemerintah Kota Surabaya tidak dapat digunakan secara maksimal, dikarenakan ketidakmampuan nelayan untuk mengikuti teknologi kapal yang diberikan.

e. Modal finansial

Jumlah penangkapan ikan tongkol lebih kurang $4 \mathrm{~kg}$, ikan tuna $6 \mathrm{~kg}$, teripang $3 \mathrm{~kg}$ dan lorjuk $2 \mathrm{~kg}$. Berdasarkan hasil tangkapan tersebut, setiap melaut pendapatan berkisar antara $\mathrm{Rp}$ 100.000,- hingga $\mathrm{Rp}$ 160.000,-. Sedangkan pengeluaran masyarakat nelayan untuk kebutuhan sehari-hari saja diatas Rp 1.200.000,- setiap bulannya dengan tanggungan keluarga rata-rata 3 orang.

Selain menjual hasil tangkapan secara langsung, masyarakat pesisir juga melakukan pengolahan ikan skala kecil seperti pengasinan, pengasapan ikan, pembuatan krupuk atau pembuatan terasi udang.

\section{Analisa Pemberdayaan Sustainable}

Livelihood di Kawasan Pesisir Kota Surabaya

Berdasarkan karakteristik sustainable livelihood yang ada di kawasan peisisir Kota Surabaya, didapatkan bahwa modal-modal yang ada dalam rangka keberlanjutan dapat dioptimalkan dengan dukungan masyarakat nelayan. Namun, kondisi masyarakat nelayan masih perlu dilakukan evaluasi untuk mengoptimalkan langkah-langkah yang tepat menuju masyarakat pesisir yang berdaya. Berikut ini merupakan analisa pemberdayaan di kawasan pesisir Kota Surabaya.

a. Modal sosial

Modal sosial dapat diartikan sebagai sumber (resource) yang timbul dari adanya interaksi antara orang-orang dalam komunitas. Pengukuran modal sosial sering dilakukan melalui hasil interaksi tersebut, seperti: terpeliharanya kepercayaan antar warga masyarakat. Interaksi dapat terjadi dalam skala individual maupun institusional. Dalam skala individual interaksi terjadi pada relasi intim antara individu yang menghasilkan ikatan emosional. Dalam skala institusional, interaksi terjadi pada saat beberapa organisasi memiliki kesamaan visi dan tujuan [6].

Sehingga sesuai dengan indikator modal sosial yaitu organisasi nelayan, tingkat kepercayaan antar nelayan dan jaringan ikatan masyarakat, maka analisa pemberdayaan dalam modal sosial dalam rangka adaptasi perubahan iklim adalah sebagai berikut :

1. Perlu adanya perbaikan sumber daya manusia untuk meningkatkan daya pikir dan kemauan dalam meningkatkan kesejahteraan

2. Perlu adanya perbaikan kondisi kelembagaan atau organisasi nelayan di kawasan pesisir, sehingga dapat menjadi wadah yang sesuai dengan kebutuhan masyarakat

3. Memanfaatkan keterikatan masyarakat antar nelayan untuk memberikan pengaruh baik mengenai peningkatan taraf hidup dan partisipasi dalam penghidupan berkelanjutan

4. Memanfaatkan forum keagamaan seperti pengajian yang diadakan rutin untuk memberikan pengetahuan tentang kualitas hidup yang layak dari sisi agama

5. Membantu membuka akses untuk penjualan hasil laut atau produk olahan ke luar daerah

\section{b. Modal alam}

Aspek penting yang perlu dicermati dalam kaitannya dengan kelestarian lingkungan adalah "Modal Alam", hal ini dapat diartikan sebagai sumberdaya alam yang mengalir dan sumberdayalayanan yang sudah tersedia (seperti tanah, air, hutan, kualitas udara, perlindungan erosi, keanekaragaman hayati, dll) hal ini berguna dalam persediaan sumber mata pencaharian yang ada [7].

Sehingga sesuai dengan indikator modal alam yaitu kesehatan lingkungan, produksi air, kepemilikan tanah dan produksi perikanan, maka analisa pemberdayaan dalam modal alam dalam rangka adaptasi perubahan iklim adalah sebagai berikut :

1. Kesadaran masyarakat tentang kesehatan lingkungan dan dampaknya perlu ditingkatkan. Hal ini akan mempengaruhi perilaku dan keseharian masyarakat

2. Menjaga kualitas air bersih dengan memberikan pengetahuan tentang tata cara penyaringan air mandiri, serta dampak yang muncul apabila mengkonsumsi air yang tidak layak minum

3. Memberikan contoh melalui organisasi atau tokoh masyarakat untuk meningkatkan hasil produksi perikanan dengan merubah pola tangkap

4. Meningkatkan daya eksplorasi nelayan

5. Memperbaiki ekosistem pesisir dengan mengajak masyarakat berkontribusi langsung, dan melakukan pemeliharaan ekosistem secara mandiri dan berkala

c. Modal fisik

Ketersediaan infrastruktur memberikan dampak terhadap sistem sosial dan sistem ekonomi yang ada di masyarakat. Maka infrastruktur perlu dipahami sebagai dasar-dasar dalam mengambil kebijakan [8].

Infrastruktur merupakan aset fisik yang dirancang dalam sistem, sehingga mampu memberikan pelayanan prima kepada masyarakat yang merujuk pada modal fisik yang menyediakan transportasi, pengairan, drainase, sampah, sanitasi dan fasilitas publik yang lain.

Sehingga sesuai dengan indikator modal fisik yaitu jumlah dan jenis alat, aksesibilitas, kondisi rumah, ketersediaan air bersih, kepemilikan kendaraan, kondisi sanitasi dan kondisi drainase, maka analisa pemberdayaan dalam modal fisik dalam rangka adaptasi perubahan iklim adalah sebagai berikut :

1. Perlu adanya kajian teknis mengenai kapasitas kapal yang digunakan yang sesuai dengan kondisi lingkungan dan juga dapat memenuhi kebutuhan nelayan sehari-hari

2. Infrastruktur yang diperlukan sudah disediakan oleh pemeirntah daerah, seperti akses jalan, sanitasi dan drainase. Namun, perlu adanya 
pemeliharaan infrastruktur secara berkala. Masyarakat dapat diikutsertakan dalam proses pemeliharaan

3. Peningkatan kesadaran mengenai pentingnya infrastruktur juga harus dimiliki oleh masyarakat agar muncul rasa memiliki

4. Perlu adanya perbaikan dan penataan permukiman dan rumah agar lebih layak huni

5. Memberikan fasilitas perdagangan yang sesuai untuk jual beli hasil laut maupun produk olahan laut

6. Memanfaatkan komunitas untuk membentuk aksesibilitas politik dengan pemerintah daerah

\section{d. Modal manusia}

Konsep modal manusia menganggap bahwa manusia merupakan suatu bentuk modal atau kapital sebagaimana bentuk-bentuk kapital lainnya, seperti mesin, teknologi, tanah, uang, dan material. Manusia sebagai human capital tercermin dalam bentuk pengetahuan, gagasan (ide), kreativitas, keterampilan, dan produktivitas kerja. Tidak seperti bentuk kapital lain yang hanya diperlakukan sebagai tools, human capital ini dapat menginvestasikan dirinya sendiri melalui berbagai bentuk investasi SDM, diantaranya pendidikan formal, pendidikan informal, pengalaman kerja, kesehatan, dan gizi serta transmigrasi [9].

Sehingga sesuai dengan indikator modal manusia yaitu tingkat pendidikan, ketrampilan dan kemampuan kerja, maka analisa pemberdayaan dalam modal manusia dalam rangka adaptasi perubahan iklim adalah sebagai berikut :

1. Perlu adanya peningkatan ketrampilan dan kemampuan kerja, sehingga nelayan di pesisir Kota Surabaya mampu beradaptasi dengan teknologi terbaru pada bidang perikanan

2. Perlu adanya peningkatan pendidikan masyarakat untuk membuka kesempatan pekerjaan yang lebih sejahtera pada saat musim paceklik

3. Meningkatkan kemauan bekerja keras pada masyarakat dengan memanfaatkan programprogram pemerintah maupun non-pemerintah

4. Melibatkan istri nelayan dalam pengelolaan hasil laut

\section{e. Modal finansial}

Modal finansial adalah sumber-sumber dari mana dana diperoleh. Modal finansial mengacu pada dana yang diberikan oleh pemberi pinjaman (dan investor) atau dana yang disetor oleh pemilik untuk membeli peralatan modal riil untuk memproduksi barang [10].

Sehingga sesuai dengan indikator modal finansial yaitu pendapatan sehari, pengeluaran, jumlah dan jenis tabungan yang dimiliki dan pinjaman, maka analisa pemberdayaan dalam modal finansial dalam rangka adaptasi perubahan iklim adalah sebagai berikut :
1. Memberikan pengetahuan bahwa peningkatan jumlah pendapatan didasarkan pada kemauan dan kerja keras dari masyarakat

2. Pengaturan pengeluaran keuangan, dengan memberikan alokasi untuk biaya pendidikan

3. Memberikan program pinjaman bergulir untuk membantu masyarakat yang belum memiliki atau sedikit modal

4. Memperbaiki proses penjualan hasil laut untuk mengoptimalkan penghasilan nelayan

Berdasarkan analisa dalam pemberdayaan melalui sustainable livelihood nelayan pesisir di Kota Surabaya, secara keseluruhan sistem modal, modal manusia memiliki peran penting untuk diperbaiki. Apabila modal manusia sebagai titik penting pemberdayaan telah dioptimalkan, maka modal lainnya akan seiring berjalan membaik sesuai dengan kondisi yang diinginkan.

Terdapat penelitian yang menunjukkan bahwa masyarakat nelayan di Sukolilo Pesisir Kota Surabaya secara faktual belum mampu mencapai penghidupan berkelanjutan (sustainable livelihood). Sebagian besar masyarakat nelayan hanya mampu mengakses setiap modal penghidupan berkelanjutan secara optimal. Dari gambar pentagon akses terlihat bahwa: (1) modal manusia berada pada tingkatan SLA sebesar 65\%, (2) modal sosial berada pada tingkatan SLA sebesar 20\%, (3) modal alam/lingkungan berada pada tingkatan SLA sebesar 50\%, (4) modal infrastruktur berada pada tingkatan SLA sebesar 60\% dan (5) modal finansial pada tingkatan SLA sebesar 30\% [1].

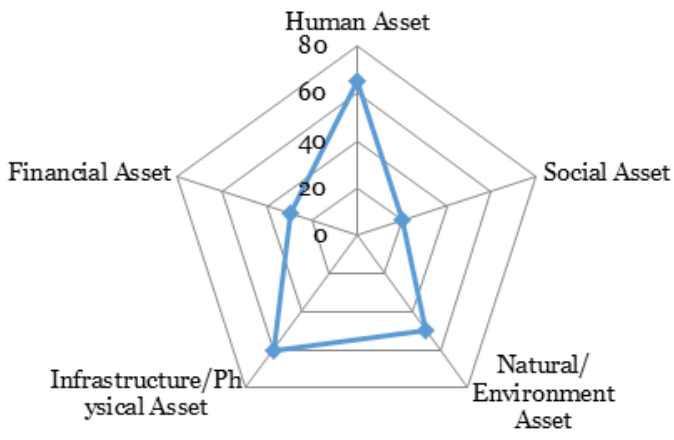

Gambar 1.Tingkat Sustainable Livelihood di Kampung Nelayan Sukolilo Kota Surabaya (Sumber : Gai, 2018)

Melalui analisa serta didukung penelitian tersebut, diperlukan adanya langkah nyata untuk menunjukkan bentuk pemberdayaan yang dapat dilakukan pada nelayan pesisir di Kota Surabaya. Langkah nyata ini akan disertai dengan konsep pemberdayaan yang sesuai dengan kondisi masyarakat nelayan pesisir.

\section{Konsep dan Langkah Pemberdayaan Berdasarkan Sustainable Livelihood}

Konsep dan langkah untuk pemberdayaan nelayan pesisir melalui sustainable livelihood, didasarkan pada analisa dan karakteristik masyarakat di pesisir Kota Surabaya. Konsep dan langkah pemberdayaan ini dibagi sesuai dengan modal dalam sustainable livelihood approach. 


\section{a. Modal sosial}

Konsep yang diterapkan dalam modal sosial untuk nelayan pesisir di Kota Surabaya antara lain :

1. Meningkatkan kepercayaan antar nelayan sehingga membentuk ikatan kekeluargaan

2. Memberikan kemudahan bagi anggota organisasi atau komunitas nelayan. Lembaga atau organisasi ini bertujuan untuk :

- Media power sharing

- Pengembangan solidaritas

- Mobilisasi sumber daya komunitas

- Membentuk pencapaian bersama

- Membentuk perilaku kebersamaan dan berorganisasi

- Membuka kesempatan untuk memperluas pemasaran

Beberapa langkah yang dapat dilakukan sesuai dengan konsep yang ada adalah :

1. Penyuluhan mengenai masyarakat madani dan berdaya pada forum rutin yang diadakan, misalnya pengajian, PKK atau rapat RT/RW

2. Identifikasi dan optimalisasi kapasitas dari kelompok-kelompok nelayan yang potensial untuk dikembangkan

3. Pembentukan kelompok usaha bersama dengan menggunakan bentuk Organisasi Pembelajaran Sinergik (OPS)

\section{b. Modal alam}

Konsep yang diterapkan dalam modal alam untuk nelayan pesisir di Kota Surabaya antara lain :

1. Memberikan penyuluhan kepada masyarakat nelayan akan perubahan kondisi cuaca yang harus diperhatikan, termasuk bentuk perubahan iklim yang terjadi di kawasan pesisir

2. Membagi pengetahuan tentang tips penangkapan ikan atau teknologi terbaru dalam menangkap ikan yang disesuaikan dengan kondisi alam saat ini

Beberapa langkah yang dapat dilakukan sesuai dengan konsep yang ada adalah :

1. Memanfaatkan forum kegiatan rutin masyarakat nelayan untuk memperluas informasi mengenai kesehatan lingkungan serta kualitas air yang layak minum

2. Memanfaatkan kelompok nelayan atau OPS untuk meningkatkan pengetahuan tentang pola tangkap ikan terbaru sesuai dengan perubahan iklim saat ini

3. Penguasaan alat-alat dan cara penangkapan yang lebih efektif

4. Penguasaan teknologi dan metode dalam pengolahan hasil laut maupun kerajinan laut lainnya

5. Permindahan atau perluasan lokasi usaha daerah penangkapan di laut

6. Pemindahan lokasi usaha dari perikanan laut menjadi perikanan darat

7. Perluasan jenis mata pencaharian yang dilakukan, sebagai pendapatan alternatif saat musim paceklik

8. Perbaikan ekosistem pesisir melalui kerjasama kelompok nelayan atau OPS dengan masyarakat yang tinggal di kawasan pesisir

\section{c. Modal fisik}

Konsep yang diterapkan dalam modal fisik untuk nelayan pesisir di Kota Surabaya antara lain :
1. Meningkatkan pemanfaatan sumber daya bahan lokal untuk mengoptimalkan jenis penjualan di kios-kios masyarakat

2. Melakukan pemeliharaan berkala pada infrastruktur dan fasilitas yang sudah dibangun

3. Memperbaiki prasarana dan sarana kawasan permukiman nelayan pesisir yang belum sesuai standar ideal

Beberapa langkah yang dapat dilakukan sesuai dengan konsep yang ada adalah :

1. Perbaikan infrastruktur yang mengalami kerusakan atau penurunan kualitas

2. Pemeliharaan infrastruktur secara berkala sebagai bentuk antisipatif terhadap kerusakan yang mungkin terjadi

3. Pembangunan area perdagangan yang diperuntukkan untuk jual beli hasil laut nelayan maupun produk olahan

4. Pembentukan akses politik antara komunitas nelayan dengan pemerintah daerah, sehingga kebijakan untuk nelayan lebih tepat

\section{d. Modal manusia}

Konsep yang diterapkan dalam modal manusia untuk nelayan pesisir di Kota Surabaya antara lain :

1. Memberikan insentif yang sesuai bagi masyarakat yang berpartisipasi dalam program atau kegiatan rutin komunitas atau organisasi

2. Meningkatkan ketrampilan dan kemampuan masyarakat dalam pengelolaan hasil laut

3. Memberikan pelatihan sesuai dengan kebutuhan pengembangan atau ciri khas masing-masing kawasan

4. Meningkatkan kualitas sumber daya manusia dengan pembinaanpendidikan baik formal maupun informal

5. Memberdayakan kaum wanita pesisir atau istri nelayan untuk mengolah kerajinan atau mengembangkan pemasaran dari hasil produksi laut

Beberapa langkah yang dapat dilakukan sesuai dengan konsep yang ada adalah :

1. Pembentukan kelas belajar non-formal antar nelayan untuk menimba dan menularkan pengalaman mengenai strategi dan teknik produksi

2. Pembentukan kelas belajar non-formal untuk wanita pesisir dan istri nelayan untuk mengolah hasil laut dan tata cara pengembangan pemasaran

3. Pemberian penyuluhan mengenai pentingnya pendidikan untuk membantu meningkatkan taraf hidup masyarakat nelayan

4. Pemberian insentif berupa informasi dan pengetahuan pada masyarakat nelayan yang terlibat aktif dalam kelembagaan nelayan ataupun OPS

e. Modal finansial

Konsep yang diterapkan dalam modal finansial untuk nelayan pesisir di Kota Surabaya antara lain :

1. Menguatkan lembaga atau organisasi lokal yang mengatur simpan pinjam pada masyarakat

2. Menjalin kerjasama dari berbagai pihak terkait sektor perikanan untuk mengembangkan permukiman nelayan dalam bentuk investasi modal, promosi mauppun teknologi

Beberapa langkah yang dapat dilakukan sesuai dengan konsep yang ada adalah : 
1. Pelaksanaan program Organisasi Pembelajaran Sinergik (OPS) untuk meningkatkan kemauan masyarakat dalam perbaikan taraf hidup dan lingkungan

2. Pemberian kemudahan dalam program pinjaman bergulir

3. Peningkatan jaringan komunikasi dan akses menuju investor untuk meningkatkan modal

4. Peningkatan pemasaran olahan hasil laut sebagai sumber finansial alternatif

\section{TEMUAN ATAU DISKUSI}

Berdasarkan hasil menggali informasi dari responden di lapangan, penangkapan ikan skala besar mulai beralih menjadi skala kecil dikarenakan kualitas ikan tangkapan skala besar yang buruk. Hal ini perlu ada kajian khusus untuk menindaklanjuti apa yang mempengaruhi buruknya hasil tangkapan skala besar di pesisir Kota Surabaya.

Selain itu, pada kawasan nelayan pesisir timur Kota Surabaya, ditemukan adanya pengaruh pembangunan jembatan di Kawasan Wisata UPTD Taman Hiburan Pantai Kenjeran Surabaya. Informasi dari responden menyebutkan bahwa jumlah tangkapanmenurun akibat adanya pembangunan jembatan tersebut.

Narasumber lainnya menyebutkan bahwa pembangunan Teluk Lamong meningkatkan pencemaran laut di pesisir Kota Surabaya, sehingga mengganggu ekosistem perikanan.

Berdasarkan temuan tersebut, adanya pembangunan infrastruktur berskala besar, seperti taman hiburan, pelabuhan, reklamasi dan pembangunan lainnya, memberikan dampak buruk pada produksi perikanan. Sehingga dengan meningkatkan pemberdayaan masyarakat untuk mengelola lima modal dasar yaitu modal sosial, modal alam, modal fisik, modal manusia dan modal finansial saja tidak menyelesaikan masalah kesejahteraan nelayan pesisir. Faktor lain yang juga berpengaruh adalah kebijakan pembangunan (penataan ruang) kawasan pesisir.

\section{E. SIMPULAN DAN SARAN}

Berdasarkan hasil dan pembahasan, didapatkan konsep pemberdayaan nelayan pesisir melalui pendekatan sustainable livelihood di Kota Surabaya sebagai bentuk adaptasi perubahan iklim dapat dilakukan dengan langkah berikut :

a. Pemberdayaan pada modal sosial

1. Penyuluhan mengenai masyarakat madani dan berdaya pada forum rutin yang diadakan, misalnya pengajian, PKK atau rapat RT/RW

2. Identifikasi dan optimalisasi kapasitas dari kelompok-kelompok nelayan yang potensial untuk dikembangkan

3. Pembentukan kelompok usaha bersama dengan menggunakan bentuk Organisasi Pembelajaran Sinergik (OPS)

b. Pemberdayaan pada modal alam
1. Memanfaatkan forum kegiatan rutin masyarakat nelayan untuk memperluas informasi mengenai kesehatan lingkungan serta kualitas air yang layak minum

2. Memanfaatkan kelompok nelayan atau OPS untuk meningkatkan pengetahuan tentang pola tangkap ikan terbaru sesuai dengan perubahan iklim saat ini

3. Penguasaan alat-alat dan cara penangkapan yang lebih efektif

4. Penguasaan teknologi dan metode dalam pengolahan hasil laut maupun kerajinan laut lainnya

5. Permindahan atau perluasan lokasi usaha daerah penangkapan di laut

6. Pemindahan lokasi usaha dari perikanan laut menjadi perikanan darat

7. Perluasan jenis mata pencaharian yang dilakukan, sebagai pendapatan alternatif saat musim paceklik

8. Perbaikan ekosistem pesisir melalui kerjasama kelompok nelayan atau OPS dengan masyarakat yang tinggal di kawasan pesisir

c. Pemberdayaan pada modal fisik

1. Perbaikan infrastruktur yang mengalami kerusakan atau penurunan kualitas

2. Pemeliharaan infrastruktur secara berkala sebagai bentuk antisipatif terhadap kerusakan yang mungkin terjadi

3. Pembangunan area perdagangan yang diperuntukkan untuk jual beli hasil laut nelayan maupun produk olahan

4. Pembentukan akses politik antara komunitas nelayan dengan pemerintah daerah, sehingga kebijakan untuk nelayan lebih tepat

d. Pemberdayaan pada modal manusia

1. Pembentukan kelas belajar non-formal antar nelayan untuk menimba dan menularkan pengalaman mengenai strategi dan teknik produksi

2. Pembentukan kelas belajar non-formal untuk wanita pesisir dan istri nelayan untuk mengolah hasil laut dan tata cara pengembangan pemasaran

3. Pemberian penyuluhan mengenai pentingnya pendidikan untuk membantu meningkatkan taraf hidup masyarakat nelayan

4. Pemberian insentif berupa informasi dan pengetahuan pada masyarakat nelayan yang terlibat aktif dalam kelembagaan nelayan ataupun OPS

e. Pemberdayaan pada modal finansial
1. Pelaksanaan program
Organisasi
Pembelajaran Sinergik (OPS) untuk meningkatkan kemauan masyarakat dalam perbaikan taraf hidup dan lingkungan 
2. Pemberian kemudahan dalam program pinjaman bergulir

3. Peningkatan jaringan komunikasi dan akses menuju investor untuk meningkatkan modal

4. Peningkatan pemasaran olahan hasil laut sebagai sumber finansial alternatif

Pada penelitian selanjutnya dapat dilengkapi dengan pertimbangan faktor kebijakan yang dilakukan pemerintah daerah serta stakeholder terkait dalam meningkatkan kesejahteraan masyarakat nelayan pesisir. Hal ini akan meningkatkan akurasi langkah yang diambil dalam meningkatkan pemberdayaan masyarakat nelayan pesisir pada penelitian ini.

\section{DAFTAR RUJUKAN}

[1] Gai, Ardiyanto M., I. Soewarni and M.M. Sir., The Concept of Community Poverty Reduction in Coastal Area of Surabaya Based on Sustainable Livelihood Approach, IOP Conference Series: Earth and Environmental Science, 2017.

[2] Purnomo, Heri A., S. H. Suryawati, I. M. Radjawane dan K. O. Sembiring, Perubahan Ikim di Wilayah Pesisir : Konsepsi dan Aplikasi Strategi Adaptasi, Penerbit ITB, 2015 .

[3] Kamaruddin, Roslina, The Sustainable Livelihoods Index: A Tool To Assess The Ability AndPreparedness Of The Rural Poor In Receiving Entrepreneurial Project,Journal of Social Economics Research, 2014.

[4] Saragih, Sebastian, Lassa Jonatan dan Ramli Afan, Kerangka Penghidupan Berkelanjutan(Sustainable Livelihood Framework), 2007.

[5] Badan Perencanaan dan Pembangunan Kota (BAPPEKO) Surabaya, Rencana Strategis Wilayah Pesisir Kota Surabaya. 2011.

[6] Suharto,Edi, Modal Sosial dan Kebijakan Publik, 2007.

[7] DFID, Sustainable Livelihood Guidance Sheets, Department for International Development, www.livelihoods.org/info/info guidancesheets.html, 2000

[8] Kodoatie, Robert J., Pengantar Manajemen Infrastruktur, Pustaka Pelajar, Yogyakarta, 2005.

[9] Fattah, Nanang, Landasan Manajemen Pendidikan, Remaja Rosdakarya, Bandung, 2004.

[10] Ekowati, S., O. Rusmana dan M. Mafudi, Akuntansi, Organisasi dan Masyarakat : Pengaruh Modal Fisik, Modal Finansial dan Modal Intelektual Terhadap Kinerja Perusahaan Manufaktur di Bursa Efek Indonesia, 2012. 